\title{
TELEPHELY VÁLASZTÁSI FELADAT MEGOLDÁSA AZ AIMMS MODELLEZŐ RENDSZERREL
}

\section{SOLVING A SITE SELECTION PROBLEM WITH THE AIMMS MODELLING SYSTEM}

\author{
Ágoston János \\ Kecskeméti Föiskola GAMF Kar, Cím: 6000, Magyarország, Kecskemét, Izsáki út \\ 10; Telefon: +76-516-300, Fax: +76-516-399, agostonjanos@gmail.com
}

\begin{abstract}
We discuss the site selection problem of the AT \& T telecommunications company, and solve it using the AIMMS modeling system. In addition, we describe the AIMMS modeling system and its structure, operation and customization. We introduce the variables and mathematical formulas used in the optimization. The telemarketing industry is mentioned together with AT \& T telecommunications company history.
\end{abstract}

Keywords: optimization, modeling, telemarketing, telecommunications, site.

\section{Összefoglalás}

A projektfeladat az AT\&T Telekommunikációs cég telephely optimalizálását mutatja be az AIMMS modellező rendszerrel. A projekt bemutatása mellett kitérünk az AIMMS modellező rendszerre, annak müködésére, felépítésére és a felhasználó által testreszabhatóságára. Bemutatjuk az optimalizálás során használt matematikai változókat és képleteket. A tanulmány során még említést nyer a telemarketing és a telekommunikáció és az AT\&T Telekommunikációs cég története.

Kulcsszavak: optimalizálás, modellezés, telemarketing, telekommunikáció, telephely.

\section{Telemarketing}

A telemarketing telefonon keresztüli marketing tevékenység, ami lehet adatbázis frissítés-építés, marketingkutatás, direktmarketing kommunikáció illetve telefonos ügyfélszolgálat. A telemarketing elönye az, hogy interaktív és rendkívül költséghatékony és alkalmas azonnali információgyüjtésre, illetve a telefonos lefedettség miatt nagy hatékonyságú. A hátránya, hogy nagy a fluktuáció a telemarketinges munkaerőpiacon és a garanciális feltételek nehezen teljesíthetőek. A telemarketing évekkel ezelött egy fejlődő iparág volt, hiszen fejlődő társadalmunk legnagyobb igényét, az emberek kényelmét szolgálta ki. Azonban manapság már nem telefonon, hanem weboldalakon keresztül történik a marketing tevékenység nagy része.

\subsection{Fluktuáció}

A szervezetből távozott munkatársak pótlására felvett munkatársak százalékos aránya az átlagos állományi létszámhoz képest, 12 hónapos időintervallumra vetítve. 


\section{AT\&T Telekommunikációs cég}

A cég története 1875-ig nyúlik vissza, ugyanis ekkor találta fel Alexander Graham Bell a telefont. Az AT\&T a 19. század folyamán a Bell System anyavállalatává vált. Ebben az időkben még nem volt nehéz monopolhelyzetbe kerülni, csak az AT\&T volt jelen a telekommunikációs piacon. 1880-ban az American Bell vezetősége létrehozott egy távolsági telefonbeszélgetéssel foglalkozó üzletágat ez később AT\&T Long Lines néven vált ismertté. Az új üzletág célja egy országos távbeszélő-hálózat létrehozása volt, egy kereskedelmileg és pénzügyileg életképes költség-struktúra kiépítése által. Ezt az üzletágat hivatalosan is egy különálló cégbe vitték be 1885. március 3-án, és ezzel megalakult az American Telephone and Telegraph Company, vagyis az AT\&T. New Yorkból indulva a hálózat 1892-re elérte Chicagót. Ezt a monopolhelyzetet az állam nem sokáig türte és 8 kisebb vállalatra bontotta. Három kisebb vállalat megalapította az SBC Communicationst, amely viszont 2005 - ben visszavásárolta a kisebb vállalatokat, amelyekre szétbontották az AT\&T-t. A régi új nevet ismételten 2005. november 18-tól használhatja a cég hivatalosan is. $\mathrm{Ez}$ a vállalat 2010 -ben a 7 . legnagyobb vállalat volt az Egyesült Államokban, közel több mint 100 millió ügyféllel.

\section{Telephely optimalizálás feladat leírása}

A cél az AT\&T cégnek az irodáit elhelyezni optimálisan és költséghatékonyan, illetve a munkavállalók optimális idő és helybeli foglalkoztatásának optimalizálása. További cél még a megoldandó problémához tartozó függvények megírása, illetve a modell felépítése a meglevő adatok felhasználásával[1][2]. Az optimalizálást az
AIMMS modellező szoftver segítségével oldottuk meg.

\section{AIMMS modellező rendszer}

Az AIMMS modellező és optimalizáló szoftver, melyet a cégek világszerte használnak. Ilyen cégek például: Avon, Shell, Esso, Nokia, LG Display. A szoftver legfontosabb része a modellépítő modul, amelyben matematikai modelleket lehet létrehozni. A modellben szereplő halmazok, paraméterek, változók és egyenletek és egyéb elemek, valamint ezek tulajdonságai egy könnyen kezelhető és átlátható fastruktúrában vannak tárolva és megjelenítve. Nem csak matematikai modellek, hanem programrészletek, úgynevezett procedúrák létrehozása is lehetséges. A szoftverben használt programozási nyelv hasonlóságot mutat más programozási nyelvekkel, legfőképp a $\mathrm{C}++$ nyelvvel. Az AIMMS - ben a modellépítést és a hibakeresést nagyban megkönnyíti a beépített Debugger és Math Program Inspector. A modellek megoldását a legkorszerübb, külső fejlesztésű csatolt szoftverek végzik, ilyenek például CPLEX, CONOPT, KNITRO, amelyekkel bonyolult, a valóságos életben használt méretü és komplexitású matematikai modellek optimalizálhatók. A grafikus felület a szoftver fö erőssége. A felület készítését sablonok teszik még egyszerübbé. Ezen felül menü és eszköztár is könnyen csatolható a felhasználói oldalakhoz. Maga a grafikus felület interaktív, könnyen és egyedien alakítható. A felépített program nem szükséges, hogy rendelkezzen saját adatbázissal mivel fejlett esetkezelöt tartalmaz, de egyébként minden adatbázissal kompatibilis, köszönhetően a beépített szabvány adatcsatolásnak (ODBC, XML). Az adatokat importálhatjuk és exportálhatjuk Excel táblákból/táblákba. 


\section{Telephely optimalizálás AIMMS modellező rendszerrel}

Az optimalizálást az adatok bevitelével kezdjük, az AIMMS modellező rendszer Edit mode - jában. A szoftverbe meg kell adni a Set, Parameter, Variable, Constraint -eket. A Set-ek index halmazok. A Parameter-ben megadjuk az adott adatokat. A Variable-ben a változókat deklaráljuk, az adatok itt változnak a számítások hatására. A Constraint-ben a számításokat végezzük el.

\subsection{Indexhalmazok}

- Irodak: az „Irodak” halmaz tartalmazza a városneveket ahol a bérbe vehető irodák elhelyezkednek. Az „i” futóindex egy tetszőleges irodát jelölhet;

- Korzetek: A „Korzetek” halmaz tartalmazza a távhívási körzetek azonosítóit. A „k” futóindex tetszőleges körzetet jelölhet.

\subsection{Adatok}

\begin{tabular}{|c|c|c|c|c|c|c|c|c|c|c|}
\hline & \multicolumn{10}{|c|}{ 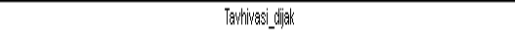 } \\
\hline & Selkrik & Erantion & Sthyo & Qfilch & St Jep & Connus & Salt Ste & Shaw & Doun & Sydney \\
\hline 204 & 92 & 9.2 & 12.4 & 12.4 & 12.4 & 118 & 11.8 & 12.4 & 12.4 & 12.4 \\
\hline 250 & 12.4 & 12.4 & 12.4 & 12.4 & 12.4 & 124 & 12.4 & 12.4 & 12.4 & 12.4 \\
\hline 306 & 11.8 & 11.8 & 12.4 & 12.4 & 12.4 & 124 & 12.4 & 12.4 & 12.4 & 12.4 \\
\hline 403 & 12.4 & 12.4 & 12.4 & 12.4 & 12.4 & 124 & 12.4 & 12.4 & 12.4 & 12.4 \\
\hline 416 & 11.8 & 11.8 & 11.8 & 11.8 & 11.8 & 109 & 10.9 & 11.8 & 11.8 & 12.4 \\
\hline 418 & 12.4 & 12.4 & 10.9 & 109 & 10.9 & 118 & 11.8 & 10.9 & 10.9 & 12.4 \\
\hline 5016 & 12.4 & 12.4 & 11.8 & 11.8 & 11.8 & 124 & 12.4 & 11.8 & 11.8 & 11.8 \\
\hline 514 & 12.4 & 12.4 & 78 & 78 & 78 & 118 & 11.8 & 10.9 & 10.9 & 12.4 \\
\hline 519 & 11.8 & 11.8 & 11.8 & 11.8 & 11.8 & 109 & 10.9 & 11.8 & 11.8 & 12.4 \\
\hline 6014 & 11.8 & 11.8 & 11.8 & 11.8 & 11.8 & 109 & 10.9 & 11.8 & 11.8 & 12.4 \\
\hline 613 & 11.8 & 11.8 & 11.8 & 11.8 & 11.8 & 106 & 10.9 & 11.8 & 11.8 & 12.4 \\
\hline 705 & 11.8 & 11.8 & 11.8 & 11.8 & 11.8 & 109 & 11.3 & 11.8 & 11.8 & 12.4 \\
\hline 709 & 12.4 & 12.4 & 12.4 & 12.4 & 12.4 & 124 & 12.4 & 12.4 & 12.4 & 11.8 \\
\hline 807 & 11.8 & 11.8 & 11.8 & 11.8 & 11.8 & 109 & 10.9 & 11.8 & 11.8 & 12.4 \\
\hline 819 & 12.4 & 12.4 & 10.9 & 10.9 & 10.9 & 118 & 11.8 & 10.6 & 10.6 & 12.4 \\
\hline 9002 & 12.4 & 12.4 & 12.4 & 12.4 & 12.4 & 124 & 12.4 & 12.4 & 12.4 & 128 \\
\hline 905 & 11.8 & 11.8 & 11.8 & 11.8 & 11.8 & 109 & 10.9 & 11.8 & 11.8 & 12.4 \\
\hline
\end{tabular}

1. ábra. Távhívási dijak városokra és körzetekre lebontva. A sorok a körzetek, az oszlopok a városok[1][2].

- Berletdij(i): az egyes irodák éves bérleti díja;
- Oraber(i): a dolgozók órabére az egyes irodák helyszínein;

- Hivasszamok(k): az egyes körzetekből érkező hívások száma;

- Tavhivasi_dijak(k,i): egyes körzetekböl egyes városokba távhívások óradíja;

- Max_dolgozo(i): a férőhelyek száma egyed irodákban.



2. ábra. Deklarálva van a Set, Parameter, Variable, Constraint [1][2].

\subsection{Döntési változók}

- Berek_e(i): bináris változó, ami azt mutatja meg, hogy az irodák közül melyeket vesszük bérbe;

- Dolgozok db(i): az egyes irodákba felvett dolgozók száma;

- Hivas_atiranyitas(k,i): megmutatja, hogy hány hívást irányítunk a $\mathrm{k}$ körzetböl az i-edik irodába;

- Teljes_berletdij;

$$
\operatorname{sum}[\text { i, Berletdij( i) *Berel_e(i) ] }
$$


- Teljes_dolgozober;

sum [i,Oraber(i)*Dolgozok_db(i)]

$* 24 * 365$

- Teljes_hivaskoltseg: a teljes távhívási díj;

$\operatorname{sum}[(\mathrm{k}, \mathrm{i})$, Hivas_iran yitas(k, i) *

Tavhivasi_dijak(k, i)]/12

- Teljes_koltseg.

Teljes_berletdij+Teljes_dolgozober

+ Teljes_hivaskoltseg

\subsection{Korlátozó feltételek}

- Csak_berbevett(i): csak olyan irodákba vehetünk fel dolgozókat amelyeket bérbe vettünk;

$$
\begin{aligned}
& \text { Dolgozok_d b(i) <= Max_dolg } \\
& \text { ozo(i) *Berel_e(i) }
\end{aligned}
$$

- Fogad(i): minden irodába annyi hívást lehet fogadni, amennyit az ott dolgozók fogadni tudnak;

$$
\begin{aligned}
& \text { Dolgozok_db(i) } * 87600>=\text { sum } \\
& {[\mathrm{k}, \operatorname{Hivas} \text { iranyitas }(\mathrm{k}, \mathrm{i})]}
\end{aligned}
$$

- Iranyit(k): minden hívást irányítani kell valamelyik irodába.

$$
\begin{aligned}
& \operatorname{Hivasszamok}(\mathrm{k})=\operatorname{sum}\left[\mathrm{i}, \text { Hivas }_{-}\right. \\
& \operatorname{iranyitas}(\mathrm{k}, \mathrm{i})]
\end{aligned}
$$

\section{Következtetések}

\begin{tabular}{|c|c|c|}
\hline & Brandon & Drum \\
\hline 204 & 78397 & \\
\hline 250 & 99202 & 13544 \\
\hline 306 & 70399 & \\
\hline 403 & & 193330 \\
\hline 416 & & 289617 \\
\hline 418 & & 122353 \\
\hline 506 & & 51854 \\
\hline 514 & & 238019 \\
\hline 519 & & 100988 \\
\hline 604 & & 131861 \\
\hline 613 & & 102583 \\
\hline 705 & & 41983 \\
\hline 709 & & 40687 \\
\hline 807 & & 17591 \\
\hline 819 & & 141881 \\
\hline 902 & & 74110 \\
\hline 905 & & 191599 \\
\hline
\end{tabular}

A feladat megoldásával egyensúlyt tudunk találni a különböző költségelemek között. A használt modellező rendszer alkalmas arra, hogy az adatokban történő változások hatását követni tudjuk.

3. ábra. Hivás átirányitás, a megoldott modell optimalizált állapota. A sorok a körzetek, az oszlopok a városok[1][2].

\section{Szakirodalmi hivatkozások}

[1]T. Spencer, A. J. Brigandi, D. R. Dargon, M. J. Sheehan: AT\&T's Telemarketing Site Selection System Offers Customer Support, AT\&T Business Operations Analysis Room 7125M1, 295 North Marple Avenue Basking Ridge,New Jersey 07920.

[2] Doug Roth, Peter Bell: Informs Case (1998), 901 Elkridge Landing Road, Suite 400, Linthicium. 